\title{
Biofuel Production from Palm Olein by Catalytic Cracking Process using ZSM-5 Catalyst
}

\author{
Rondang Tambun ${ }^{1, \bowtie}$, Oktris Novali Gusti ${ }^{1}$, Muhammad Anshori Nasution ${ }^{2}$, Rangga \\ Pramana Saptawaldi ${ }^{1}$
}

\section{DOI 10.15294/jbat.v6i1.8733}

${ }^{1}$ Department of Chemical Engineering, Universitas Sumatera Utara, Padang Bulan, Medan 20155, Indonesia

${ }^{2}$ Pusat Penelitian Kelapa Sawit, J1. Brigjen Katamso No. 51, Medan 20158, Indonesia

\begin{tabular}{l} 
Article Info \\
\hline Article history: \\
Accepted \\
February 2017 \\
Approved \\
May 2017 \\
Published \\
June 2017 \\
\hline Keywords : \\
biofuels \\
catalytic cracking \\
palm olein \\
ZSM-5 \\
\hline
\end{tabular}

\begin{abstract}
The depletion of fossil energy reserves raises the potential in the development of renewable fuels from vegetable oils. Indonesia is the largest palm oil producer in the world, where palm oil can be converted into biofuels such as biogasoline, kerosene and biodiesel. These biofuels are environmentally friendly and free of the content of nitrogen and sulfur through catalytic cracking process. In this research, palm olein is used as feedstock using catalytic cracking process. ZSM-5 is used as a catalyst, which has a surface area of $425 \mathrm{~m}^{2} / \mathrm{g}$ and Si/Al ratio of 50. Variables varied are the operating temperature of $375^{\circ} \mathrm{C}-450{ }^{\circ} \mathrm{C}$ and reaction time of 60 minutes - 150 minutes. The result shows that the highest yield of liquid product is $84.82 \%$. This yield is obtained at a temperature of $400{ }^{\circ} \mathrm{C}$ and reaction time of 120 minutes. The yield of the liquid product in the operating conditions consisting of $\mathrm{C}_{6}-\mathrm{C}_{12}$ amounted to $19.47 \%$, $\mathrm{C}_{14}-\mathrm{C}_{16}$ amounted to $16.56 \%$ and the $\mathrm{C}_{18}-\mathrm{C}_{28}$ amounted to $48.80 \%$.
\end{abstract}

\section{INTRODUCTION}

The depletion of fossil energy sources leads to a fuel crisis as it happens today. This leads to the development of renewable fuels from plants, especially palm oil, where the fuel is environmentally friendly and free of sulfur or nitrogen This leads to the development of renewable fuels from plants, especially palm oil, where the fuel is environmentally friendly and free of sulfur or nitrogen (Chew \& Bhatia, 2009; Tamunaidu \& Bhatia, 2007). Palm olein is one of the alternative raw materials that can be used for renewable fuels. Palm olein is a liquid fraction of palm oil that has been fractionated (Karimah, 2014). The number of palm olein in Indonesia is so abundant that the development of palm olein utilization can be done, which is currently Indonesia is the largest palm oil producing country in the world.

Catalytic cracking is a chemical process that can be applied in the manufacture of biofuel from palm olein. Palm olein can be cracked into biofuel because it has a long carbon chain. This process can produce a number of liquid hydrocarbon fuels such as biogasoline (Rohmah et al., 2012), biodiesel (Mota et al., 2014) and kerosene (Sirajuddin et al., 2013). This process has been proven to produce biofuel from various raw materials such as palm oil, rubber seed oil, soybean oil and others. The catalytic cracking process uses heterogeneous catalysts to speed up the reaction.

(C) 2017 Semarang State University

\footnotetext{
${ }^{\square}$ Corresponding author:

Department of Chemical Engineering, Universitas Sumatera Utara, Padang Bulan,

Medan 20155, Indonesia

ISSN 2303-0623

E-mail: rondang@usu.ac.id | rondang_tambun@yahoo.com
} 
Some of the catalysts commonly used in this catalyzed cracking are Al-SBA-15 (Ooi \& Bhatia, 2007), natural zeolite (Rohmah et al., 2012), silica alumina, ZSM-5 (Sirajuddin et al., 2013) and several other catalysts. Chew and Bhatia also conducted research using raw materials of crude palm oil (CPO) and cooking oil with HZSM-5 catalyst and REY catalyst. From the result of the research, it is known that HZSM-5 gives higher yield of liquid product. It also found that the use of HZSM-5 catalysts produced more gasoline components than beta zeolites which tend to produce kerosene and more biodiesel (Chew \& Bhatia, 2009). Zeolite is a catalyst commonly used in catalytic cracking process. Zeolites have advantages such as thermal stability, selectivity (Taufiqurrahmi et al., 2010) and its highly ordered structure (Sprung \& Bert, 2014). ZSM-5 (Zeolite Socony Mobil-5) is one of a kind zeolite that can be used as a catalyst in catalytic cracking. Zeolite ZSM-5 is aluminum-silicate with high Si content and low Al. The center on the part around $\mathrm{Al}$ is very acidic. Substitution of $\mathrm{Al}^{+3}$ by $\mathrm{Si}^{+4}$ requires the presence of an additional positive charge. If $\mathrm{H}^{+}$ exists, the acidity of the zeolite is high (Buzetzki et al., 2009).

Based on the above description, this research will examine the effect of temperature and time of operation on yield and distribution of biofuel production, and obtain the best condition for the highest biofuel yield from palm olein catalytic cracking process using ZSM-5 catalyst.

\section{MATERIALS AND METHODS}

\section{Materials and Equipment}

Palm olein used in this study are commercial oils and ZSM-5 catalysts obtained from international zeolyst with $\mathrm{Si} / \mathrm{A} 150$ ratio. This study use a pressurized batch reactor with 4848 parr type and gas chromatography using FID (Flame Ionized Detector) to analyze raw material content and hydrocarbon content in liquid product.

\section{Calcination of Catalyst}

Catalyst NH4-ZSM-5 (CBV5524G) with $\mathrm{Si} / \mathrm{Al}$ ratio of 50 is calcined at $600{ }^{\circ} \mathrm{C}$ for 6 hours to convert it into H-ZSM-5 (Chew \& Bhatia, 2009).

\section{Catalytic Cracking of Palm Olein}

The reaction is carried out in a batch reactor where the operating pressure depends on reaction time and reaction temperature. Palm olein of $500 \mathrm{~g}$ and a catalyst of $10 \mathrm{~g}$ ( $2 \%$ of the raw material) are put into the reactor. The reaction starts when the reactor temperature has reached the reaction temperature, where in this study the reaction time is used in 60 minutes - 150 minutes and the reaction temperature of $375^{\circ} \mathrm{C}-450^{\circ} \mathrm{C}$. After the reaction is complete, the reactor is cooled to room temperature where it will form the product in three phases of liquid, solid and gas. The solid product and liquid product are separated by filtration while the amount of gas is calculated based on the mass balance by subtracting the initial amount of raw material by the amount of liquid product and the obtained solids.

\section{RESULTS AND DISCUSSIONS}

\section{Raw Material Analysis}

The fatty acid content affects the catalytic cracking process, where the content of unsaturated bonds increases the formation of aromatic hydrocarbons (Doronin et al., 2013). These aromatic hydrocarbons can polymerize which leads to the coke formation (Taufiqurrahmi \& Bhatia, 2011).

Table 1 shows the results of the raw material components analysis in the palm olein using gas chromatography.

Table 1. Palm olein components.

\begin{tabular}{ll}
\hline Components & $\begin{array}{l}\text { Composition } \\
\mathbf{\%}(\mathbf{w} / \mathbf{w})\end{array}$ \\
\hline Lauric acid $\left(\mathrm{C}_{12: 0}\right)$ & 0.2208 \\
Myristic acid $\left(\mathrm{C}_{14: 0}\right)$ & 1.0710 \\
Palmitic acid $\left(\mathrm{C}_{16: 0}\right)$ & 38.647 \\
Palmitoleic acid $\left(\mathrm{C}_{16: 1)}\right)$ & 0.2048 \\
Stearic acid $\left(\mathrm{C}_{18: 0)}\right)$ & 3.5960 \\
Oleic acid $\left(\mathrm{C}_{18: 1}\right)$ & 43.2073 \\
Linoleic acid $\left(\mathrm{C}_{18: 2}\right)$ & 12.2946 \\
Linolenic acid $\left(\mathrm{C}_{18: 3}\right)$ & 0.2812 \\
Arachidic acid $\left(\mathrm{C}_{20: 0}\right)$ & 0.3241 \\
Eicosenoic acid $\left(\mathrm{C}_{20: 1}\right)$ & 0.1526 \\
\hline
\end{tabular}

\section{Effect of Catalyst Calcination on Product Composition}

In the catalytic cracking process of palm oil three-phase product was produced, namely in the form of solid, gas and liquid product. The effect of catalyst calcination on the composition of the product in solid phase, liquid (liquid product in the range $\mathrm{C}_{6}-\mathrm{C}_{28}$ ) and gas can be seen Figure 1 , where 


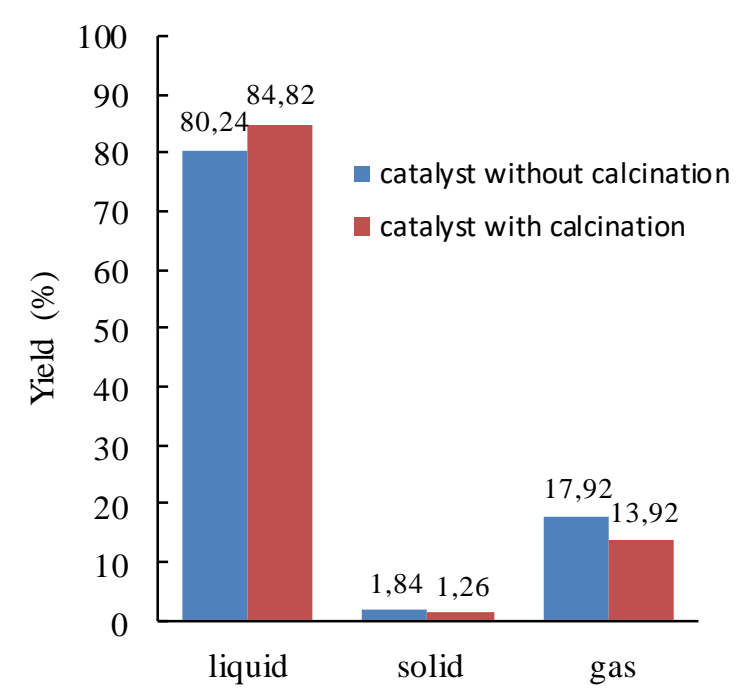

Figure 1. Effect of catalyst calcination on product composition.

the reaction is carried out under operating conditions when the temperature is $400{ }^{\circ} \mathrm{C}$ and the reaction time is 120 minutes. The results showed that the use of a catalyst by the calcination process give a higher value of the liquid product than using a catalyst without calcination, where obtained the yield of $84.82 \%$ is obtained on the use of catalyst with calcination and $80.24 \%$ on the use of catalyst without calcination. The use of catalysts with calcination also decreases gas formation by $4 \%$ and solids by $0.58 \%$ when compared with catalyst use without casination.

Figure 2 shows the effect of calcination on the liquid product yield distribution. The distribution of the liquid product formed is divided into three parts: $\mathrm{C}_{6}-\mathrm{C}_{12}, \mathrm{C}_{14}-\mathrm{C}_{16}$, and $\mathrm{C}_{18}-\mathrm{C}_{28}$. Components with carbon $\mathrm{C}_{18}-\mathrm{C}_{28}$ bond on the process without using calcined catalyst is obtained value of $64.05 \%$, and the process using calcined catalyst is obtained value of $57.53 \%$. The $\mathrm{C}_{14}-\mathrm{C}_{16}$ components have the highest value in the process by using a calcined catalyst with a value of $19.52 \%$, and the process without using calcined catalyst is obtained value of $10.29 \%$.

Calcination of the ZSM-5 catalyst has changed the zeolite cation from $\mathrm{NH}_{4}{ }^{+}$to $\mathrm{H}^{+}$(Chew and Bhatia, 2009) and can also change the acidity of the catalyst ( $\mathrm{Lu}$ et al., 2005). From the research conducted at temperature of $400^{\circ} \mathrm{C}$ and at the time of reaction of 120 minutes, the liquid product formed has a shorter chain carbon content $\left(<\mathrm{C}_{16}\right)$ larger on the catalyst with calcination than the catalyst without calcination, but the long chain

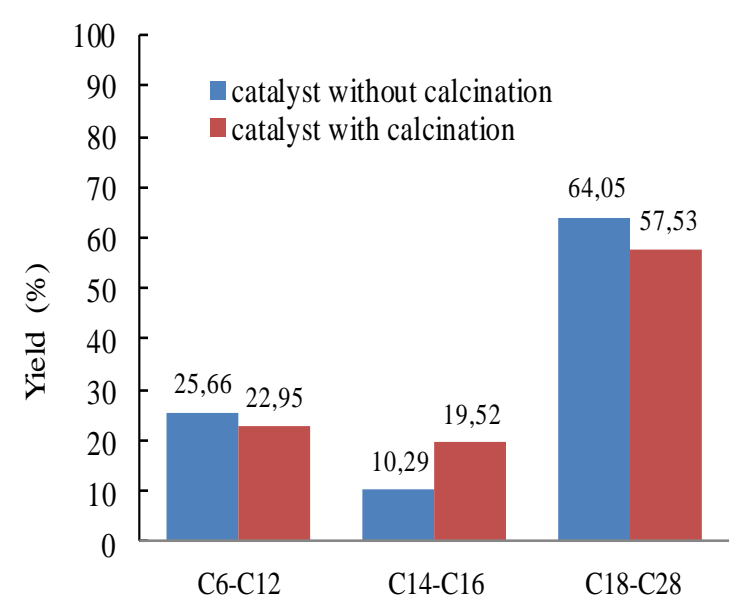

Figure 2. Effect of calcination on liquid product distribution.

hydrocarbon content $\left(>C_{18}\right)$ is greater in the catalytic cracking process using a catalyst without calcination.

\section{Effect of Temperature and Reaction Time on Liquid Product Yield}

The effect of reaction time and reaction temperature at $375^{\circ} \mathrm{C}-450^{\circ} \mathrm{C}$ on the yield of liquid product can be seen in Figure 3. In the figure can be seen that the highest yield of liquid product is obtained at a temperature of $400^{\circ} \mathrm{C}$ and at reaction time of 120 minutes with a value of $84.82 \%$ and decreased at a later time. At the reaction temperature of $425^{\circ} \mathrm{C}$ and $450^{\circ} \mathrm{C}$, the yield of liquid product showed a downward trend with increasing reaction time, with maximum liquid product yield value at minute 60 with value of $81.94 \%$ and $74.06 \%$ respectively. At $375^{\circ} \mathrm{C}$, the yield of liquid product is still increased until the reaction time of 150 minutes, where the lowest yield of liquid product is obtained at $375^{\circ} \mathrm{C}$ at reaction time of 60 minutes with the value of $54.44 \%$, and the highest yield is obtained at reaction time of 150 minutes with the value of $83.04 \%$.

The results of this study are in accordance with the predictions of $\mathrm{Li}$, et al (2014) which states that the yield of liquid product increases with increasing reaction temperature, but will decrease after obtaining maximum yield value by increasing the reaction temperature. This is because some liquid product will be cracked into gas product and will decrease yield on liquid product. This makes the product liquid yield of catalytic cracking 


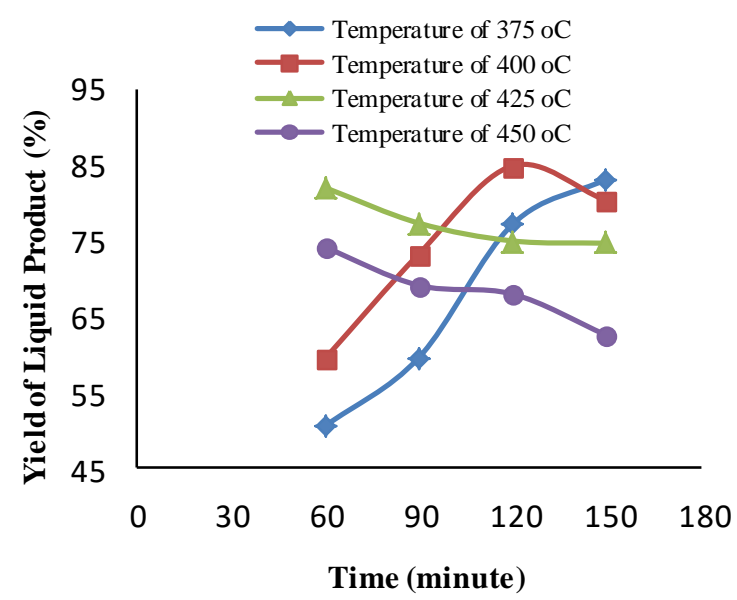

Figure 3. Effect of reaction time on yield of liquid product at temperature of $375{ }^{\circ} \mathrm{C}-450$ ${ }^{\circ} \mathrm{C}$.

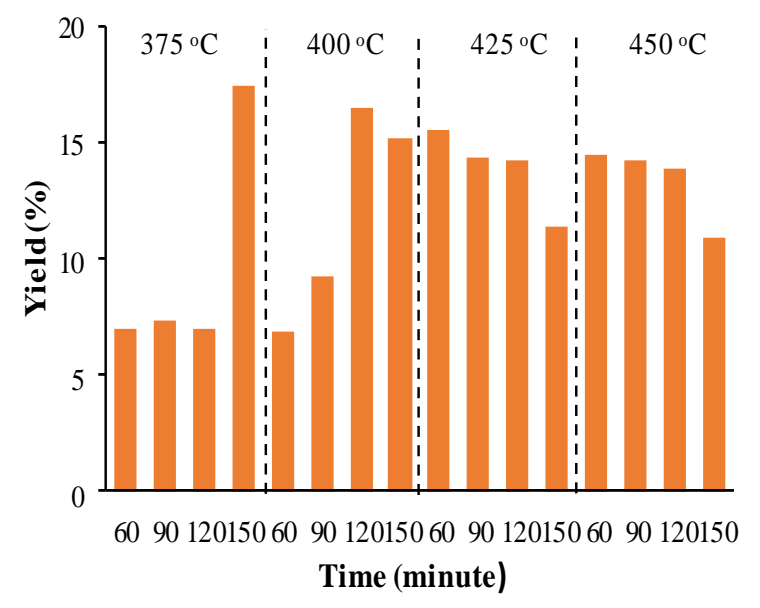

Figure 4. Influence of reaction time and temperature reaction to liquid product distribution of $\mathrm{C}_{14}-\mathrm{C}_{16}$.

decrease with increasing time and reaction temperature after reaching the maximum value.

Compared to the similar studies with this study performed by Li, et al. (2014) and Sirajuddin, et al. (2013), the results obtained in this study are quite good. In a study conducted by Li, et al (2014), they performed catalytic cracking process using rubber seed oil as raw material and USY as catalyst. They could achieve the highest liquid product yield about $75.6 \%$ at temperature of $420^{\circ} \mathrm{C}$ in 90 minutes. While in research conducted by Sirajuddin, et al. (2013), they did a catalytic cracking process by using a fix bed micro reactor using palm oil as a raw material and HZSM-5 as catalyst, with variation of temperature and $\mathrm{N}_{2}$ flow rate. They achieved the highest yield consists of gasoline of $28.87 \%$,

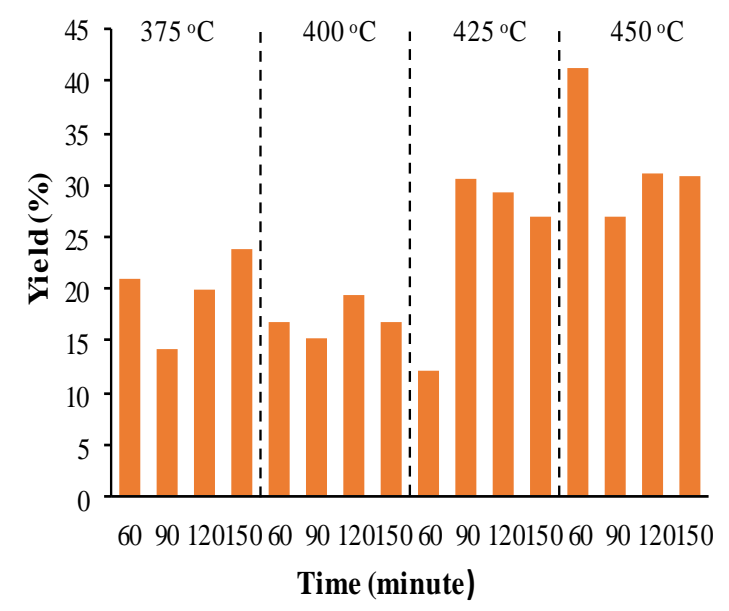

Figure 4. Influence of reaction time and temperature reaction to liquid product distribution of $\mathrm{C}_{6}-\mathrm{C}_{12}$.

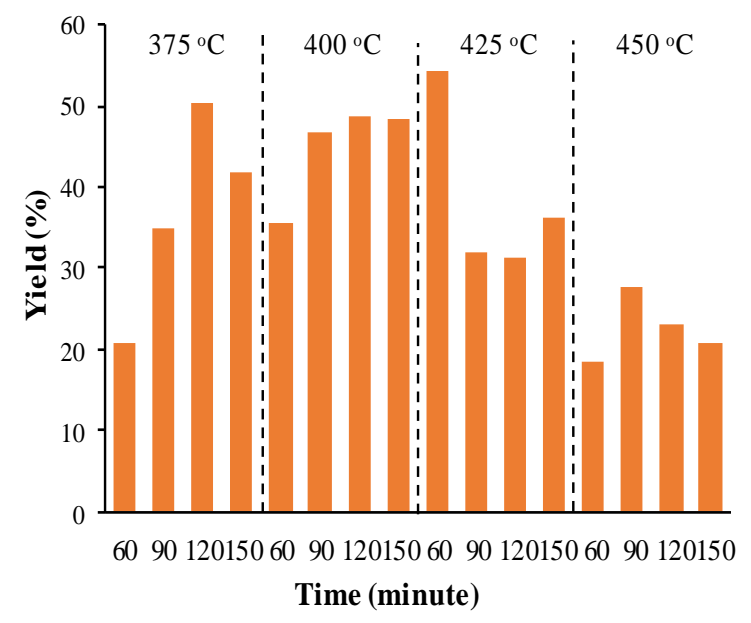

Figure 4. Influence of reaction time and temperature reaction to liquid product distribution of $\mathrm{C}_{18}-\mathrm{C}_{28}$.

kerosene of $16.70 \%$ and diesel of $1.2 \%$. This yield is obtained at a temperature of $450^{\circ} \mathrm{C}$ and $\mathrm{N}_{2}$ flow rate of $100 \mathrm{ml} / \mathrm{min}$.

\section{Liquid Product Distribution at Various Temperature and Reaction Time}

Liquid product of the catalytic cracking process of palm olein contains hydrocarbons with varying amounts of $\mathrm{C}$ chains, where the product distributions are grouped by carbon bonds, carbon bonds of $\mathrm{C}_{5}-\mathrm{C}_{12}$ are identified as gasoline, carbon bonds of $\mathrm{C}_{13}-\mathrm{C}_{14}$ are identified as jet, carbon bonds of $\mathrm{C}_{15}-\mathrm{C}_{17}$ are identified as kerosene fuels and carbon bonds of $\mathrm{C}_{18}-\mathrm{C}_{28}$ are identified as gas oil/diesel (Ortega et al., 2006). The effect of reaction time and reaction temperature on the 
distribution of liquid product of $\mathrm{C}_{6}-\mathrm{C}_{12}, \mathrm{C}_{14}-\mathrm{C}_{16}$ and $\mathrm{C}_{18}-\mathrm{C}_{28}$ in the temperature range of $375^{\circ} \mathrm{C}-450^{\circ} \mathrm{C}$ can be seen in Figures 4, 5 and 6, where these distributions are obtained from liquid product analysis by using gas chromatography.

Figure 4 shows that the highest yield of liquid product of $\mathrm{C}_{6}-\mathrm{C}_{12}$ chain is obtained at temperature of $450^{\circ} \mathrm{C}$ and reaction time of 60 minutes with value of $41.21 \%$. In Figure 5 can be seen that the highest yield of liquid product of $\mathrm{C}_{14^{-}}$ $\mathrm{C}_{16}$ chain is obtained at $375^{\circ} \mathrm{C}$ and reaction time 150 minutes with value $17.42 \%$, and figure 6 shows the liquid product with the highest of $\mathrm{C}_{18}-\mathrm{C}_{28}$ chain is obtained at temperature of $425^{\circ} \mathrm{C}$ and reaction time of 60 minutes with a value of $54.17 \%$.

From the results of this study also obtained that the longer reaction time and higher reaction temperature gives different values to the value of the liquid product distribution, where the complexity of the reaction of palm olein catalytic cracking process can provide many possible reactions or products formed. In this catalytic cracking process, there are several processes occurring such as cracking, deoxygenation, oligomerization, aromatization, alkylation, isomerization and polymerization (Doronin et al., 2013).

Thermal decomposition of triglycerides and heavy oxygenated hydrocarbon groups always start at a temperature of $240{ }^{\circ} \mathrm{C}-300{ }^{\circ} \mathrm{C}$ and this catalytic cracking temperature is in the range of 300 ${ }^{\circ} \mathrm{C}-500{ }^{\circ} \mathrm{C}$ (Luque et al., 2011). From the results of this study also are found the patterns of product distribution, where the liquid product of $\mathrm{C} 6-\mathrm{C} 12$ at a temperature of $450^{\circ} \mathrm{C}$ in all the reaction time and temperature of $425^{\circ} \mathrm{C}$ in reaction time 90 minutes - 150 minutes have higher yield than other operating conditions. Liquid product of $\mathrm{C}_{14-} \mathrm{C}_{16}$ at temperature of $375{ }^{\circ} \mathrm{C}$ and reaction time of 150 minutes, at temperature of $400{ }^{\circ} \mathrm{C}$ and reaction time of 120 minutes - 150 minutes, and at temperature of $425^{\circ} \mathrm{C}$ and $450^{\circ} \mathrm{C}$ in a reaction time of $60{ }^{\circ} \mathrm{C}-120^{\circ} \mathrm{C}$ have a higher yield than other operating conditions. Liquid product between $\mathrm{C}_{18^{-}}$ $\mathrm{C}_{28}$ at temperature of $375{ }^{\circ} \mathrm{C}$ and reaction time of 120 minutes - 150 minutes, at $400^{\circ} \mathrm{C}$ of temperature and reaction time of 90 minutes - 120 minutes, and $425{ }^{\circ} \mathrm{C}$ of temperature at reaction time of 60 minutes has a higher yield value than other operating conditions. From the results obtained above, it is found that the highest liquid product for $\mathrm{C}_{6}-\mathrm{C}_{12}, \mathrm{C}_{14}-\mathrm{C}_{16}$ and $\mathrm{C}_{18}-\mathrm{C}_{28}$ is not obtained under one operating condition, but each product has the best temperature and time conditions to obtain the highest yield value, so it can be stated that the liquid product composition produced will fluctuate when the temperature and reaction time are changed.

\section{CONCLUSIONS}

The use of ZSM-5 catalysts with calcination produces more products with short carbon chains than by using a catalyst without calcination. The variation of reaction temperature and reaction time in the catalytic cracking process of palm olein provide a fluctuating dispersion pattern for catalytic cracking products. In this research, the highest liquid product yield is $84.82 \%$ at reaction temperature of $400{ }^{\circ} \mathrm{C}$ and reaction time of 120 minutes.

\section{ACKNOWLEDGEMENTS}

The authors would like to thank Oil Palm Research Center (PPKS) Medan which has facilitated this research.

\section{REFERENCES}

Buzetzki, E., Katarina, S., Jan, C. 2009. Zeolite Catalyst in Cracking Natural Triacylgliserols. $\quad 44^{\text {th }} \quad$ International Petroleum Conference.

Chew, T. L., Bhatia, S. 2009. Effect of Catalyst Additives on the Production of Biofuels from Palm Oil Cracking in a Transport Riser Reactor. Bioresource Technology. 100: 2540-2545.

Doronin, V. P., Potapenko, O. V., P.V. Lipin, P. V., Sorokina, T. P. 2013. Catalytic Cracking of Vegetable Oils and Vacuum Gas Oil. Fuel. 106: 757-765.

Karimah, A. 2014. Availability of Different Types of Palm Olein and Their Performance During Deep Frying. Journal of International Scientific Publications: Agriculture and Food. 2: 511-520.

Li, L., Keijing, Q., Junming, X., Fusheng, L., Shiwei, L., Shitao, Y., Congxia, X., Baoquan, Z., Xiaoping, G. 2014. Liquid Hydrocarbon Fuels from Catalytic Cracking of Rubber Seed Oil Using USY as Catalyst. Fuel. 123: 189-193.

Lu, J., Zhen, Z., Chunming, X, Aijun, D., Pu Zhang. 2005. Effects of Calcination 
Temperature on the Acidity and Catalytic Performances of HZSM-5 Zeolite Catalysts for the Catalytic Cracking of nButane. Journal of Natural Gas Chemistry. 14: 213-220.

Luque, R., Juan, C., James, C. 2011. Handbook of Biofuel Production. UK: Woodhead Publishing Limited.

Mota, S.A.P da., Mancio, A.A., Lhamas, D.E.L., Abreu, D.H de., Silva, M.S. da., Santos, W.G. dos., Castro, D.A.R. de., Oliveira, R.M. de., Ara Ujo, M.E., Borges, L.E.P., Machado, N.T. 2014. Production of Green Diesel by Thermal Catalytic Cracking of Crude Palm Oil (Elaeis guineensis Jacq) in a Pilot Plant. Journal of Analytical and Applied Pyrolysis. 110: 1-11.

Ooi, Y. S, Bhatia, S. 2007. Aluminum Containing SBA-15 as Cracking Catalyst for the Production of Biofuel from Waste Used Palm Oil. Microporous and Mesoporous Materials. 102: 310-317.

Ortega, D., Norena, L, Aguilar, J., Hernandez, I., Ramirez, V. 2006. Recycling of Plactic Materials Employing Zeolite and MCM-41 Material. Revista Mexicana de Ingeniería Química. 5(3): 189-195.

Rohmah, E. N., Rochmat, A., Sumbogo, S. D. 2012. Bio-gasoline from Catalytic
Hydrocracking Reaction of Waste Cooking Oil Using Bayah Natural Zeolite. International Journal of Environment and Bioenergy. 3(3): 201-209.

Sirajuddin, N., Kamaruzaman, J., Setyawati, Y., La I., Ahmad, R. 2013. Biofuel Production from Catalytic Cracking of Palm Oil. World Applied Sciences Journal. 26: 6771.

Sprung, C., Bert, M. W. 2014 Dispersion and Orientation of Zeolite ZSM-5 Crystallite within a Fluid Catalytic Cracking Catalyst Particle. Chemistry European Journal. 20: $3667-3677$

Tamunaidu, P., Bhatia, S. 2007. Catalytic Cracking of Palm Oil for the Production of Biofuels: Optimization Studies. Bioresource Technology. 98:3593-3601.

Taufiqurrahmi, N., Bhatia, S. 2011. Catalytic Cracking of Edible and Non-Edible Oils for the Production of Biofuels. Energy and Evironmental Science. 4: 1087-1112.

Taufiqurrahmi, N., Mohamed, A.R., Bhatia, S. 2010. Deactivation and coke combustion studies of nanocrystalline zeolite beta in catalytic cracking of used palm oil. Chemical Engineering Journal. 163(3): 413-421. 